\title{
Factors Influencing the Success of Participatory Egovernment Applications in Romania and South Korea
}

\author{
Greg Porumbescu, * Catalin Vrabie,** Jiho Ahn, *** and Tobin Im****
}

\begin{abstract}
While participatory e-government is increasingly advocated, few studies have investigated whether it is feasible across all national contexts. This study investigates how certain contextual features influence the success of participatory applications of e-government. In particular, it assesses how the political, economic, and social context in which a particular government operates influence the introduction of participatory e-government, and compares participatory e-government applications in Romania and South Korea. These nations possess important similarities and differences in their political, social, and economic contexts. The study results suggest that the success of participatory e-government projects is to a large extent contingent upon political and economic factors and less related to social factors.
\end{abstract}

Keywords: Egovernment, Citizen Participation, Comparative Study

* Greg Porumbescu is a PhD student in the Graduate School of Public Administration at Seoul National University and lecturer in the Department of Public Administration at Kyonggi University. His research interests include e-government, government transparency, and trust in the public sector. E-mail: gporumbescu@gmail.com

** Catalin Vrabie is an assistant professor at the National School of Political Science and Public Administration in Romania. His research interests include e-government and innovation in the public sector. E-mail: cataloi@yahoo.com

*** Jiho Ahn is a postdoctoral researcher at Korea University. He received his $\mathrm{PhD}$ from the Free University of Berlin. His research interests include e-government, comparative administration, and administration in North Korea. E-mail: braudel2@snu.ac.kr

***** Tobin Im, corresponding author, is a professor in the Graduate School of Public Administration at Seoul National University. His current research focuses on government competitiveness and organization theory. This work was supported by a grant from the National Research Foundation of Korea (NRF-2011-330-B00195 [I00035]). E-mail: tobin@snu .ac.kr.

Manuscript received February 17, 2012; out for review February 23, 2012; review completed April 15, 2012; accepted April 18, 2012.

The Korean Journal of Policy Studies, Vol. 27, No. 1 (2012), pp. 1-21.

(C) 2012 by the GSPA, Seoul National University 


\section{INTRODUCTION}

Over the past few decades, e-government has emerged as a salient topic in the field of public administration. Accordingly, a litany of research has sought to describe implications said to stem from governments' application of this new administrative tool. To date, such research efforts, and the implications they describe, can be categorized into two veins. The first can be considered internally oriented in that it explores the impact of e-government adoption on the internal processes of government and bureaucracy (Brewer, Neubauer, \& Geiselhary, 2006; Danziger \& Andersen, 2002; Im, Porumbescu, \& Lee, forthcoming). The second can be considered externally oriented, as it is primarily interested in understanding how government's use of e-government affects relationships with actors outside of the government, such as citizens (Ahn \& Bretschneider 2011; Gerodimos, 2006 Macintosh, 2004; Welch, Hinnant, \& Moon, 2005).

Academics have also attempted to better understand the social and administrative features that serve to influence the adoption and application of e-government (Ahn \& Bretschneider, 2011; Fountain 2001; Im et al., forthcoming; Layne \& Lee, 2001; Yildiz 2007). The results of such research have contributed to the creation of various e-government adoption models, and have advanced both practical and theoretical understanding of prerequisites for effective e-government implementation (Yildiz, 2007).

E-government adoption models often illustrate a gradual evolution of e-government application from internal and efficiency-oriented toward external and participationoriented (Chadwick \& May, 2003; Layne \& Lee, 2001). However, a growing body of research is finding that the evolution of e-government tends to slow as governments move toward participatory applications (Brewer et al., 2006). This slowdown has been interpreted as government aversion to increasing levels of citizen participation and its preference for efficiency-oriented applications (Moon \& Norris, 2005).

The internally oriented emphasis that has been argued to be common among egovernment adoption strategies has come under criticism, with many in the academic community arguing that such applications of this new administrative tool simply serve to reinforce the status quo rather than ushering in a new, more democratic era (Brewer et al., 2006; Danziger \& Andersen, 2002; Im et al., forthcoming; Kraemer \& King, 2006). However, advocacy for externally oriented applications of e-government tends to be general, and does not go into much detail when explaining whether such applications are suitable for all contexts or only in certain settings. ${ }^{1}$ This oversight is significant

1. While prior research has explained that certain prerequisites for e-government adoption 
because it is important to understand how different contextual features may contribute to the success of certain applications of e-government (Heeks, 2005).

This study attempts to fill that gap in the literature with a focus on participatory applications of e-government—which it defines as the use of e-government to expand interaction between citizens and their government (Chadwick \& May 2003), where interaction refers to citizens' ability to obtain public services and exchange information with their government online. Few studies have attempted cross-national comparisons to describe how specific national contexts may influence the adoption of internally and externally oriented applications of e-government.

In particular, this study assesses how the political, economic, and social characteristics of a particular government's context influence the success of participatory applications of e-government. In doing so, it builds upon existing descriptive models of e-government adoption by attempting to identify the contextual features of a given society that are associated with successful participatory applications of e-government. Such research is relevant because, despite growing calls for more participatory applications of e-government, few studies have attempted to understand what conditions should be present for such e-government applications to actually work. Such an understanding is important because, while e-government is often said to be a means of enhancing government competitiveness among developing nations (VNCI, $\mathrm{Vu}$ and West, 2005), previous research has found that e-government initiatives in developing nations often fail (Heeks, 2003).

This study compares the relationships between contextual factors and applications of e-government in Romania and South Korea. These two nations were selected because they possess important political, social, and economic similarities and differences. They also possess a similar timeline with regard to the evolution of their democracies, which makes comparison of their participatory e-government applications particularly interesting. The projects selected for comparison, Government for Citizens (G4C) in South Korea and e-guvernare in Romania, are analyzed and compared in the case study section of this article.

\section{THEORETICAL FRAMEWORK}

A variety of valid definitions of e-government exist. This study defines it as government's use of information and communications technology, such as the Internet, for

exist, it does not distinguish whether such adoption is internally or externally oriented—an important distinction. 
purposes of internal management of information and public services, and as a means of mediating government interaction with citizens through information provision and soliciting citizen involvement in administrative processes (Kumar \& Best, 2006; Snellen, 2007; UN \& ASPA, 2001; Yildiz, 2007). This definition highlights two distinct areas for e-government application. The first is internal and emphasizes administrative efficiency (Chadwick \& May, 2003; Danziger \& Andersen, 2002), and the second is external and emphasizes citizens' involvement (Brewer et al. 2006; Morris $\&$ Moon, 2005). ${ }^{2}$ The externally oriented applications of e-government have been a topic of particular contention (Brewer et al., 2006; Im et al., forthcoming; Morris \& Moon, 2005; Yildiz, 2007).

Traditionally, the internal administrative processes of government have been rather isolated from external actors, which has led many (primarily nongovernment) actors to argue for greater external transparency and accountability of public organizations (Halachmi, 2005; Thomas, 1998). When citizens and other nongovernment actors are more able to hold their government accountable to the will of the people, and to access government-related information, the overall quality of democracy is said to increase (Brewer et al., 2006; Dahl, 1989; Michels, 2011). For this reason, advocates of externally oriented e-government applications are numerous and include international organizations such as the United Nations (UNPAN, 2010), politicians (Ahn \& Bretschneider, 2011), and civil society (Yang, 2003).

The decision to enhance organizational transparency and accountability to external actors requires a thoughtful assessment of the tradeoffs often said to exist between the extent to which an organization is transparent and accountable externally and involves citizen participation, and the effectiveness and efficiency of its administrative processes (Denhardt \& Denhardt, 2006; Halachmi, 2002). Indeed, a substantial number of scholars have argued that there is a negative relationship between increased citizen involvement in administrative processes and organizational performance (Neshkova \& Guo, 2011).

Among the reasons proposed for this pattern, a major theme concerns reduced efficiency of administrative processes, as each decision tends to cost more and take longer to make when there is greater citizen participation (Irvin \& Stansbury, 2004; Stivers, 1990). Subsequently, actors within a bureaucracy are likely to hesitate in adopting externally oriented applications of e-government, which can reduce administrative efficiency, and instead to prefer internally oriented applications, which are likely to

2. This study assumes that internal actors will exhibit a preference for internal applications of e-government, while external actors will exhibit a preference for externally oriented applications. This assumption is based on arguments found throughout the existing literature on e-government adoption cycles (Chadwick \& May, 2003; Layne \& Lee, 2001; Yildiz, 2003). 
bolster the performance of existing administrative processes, for which they are accountable.

However, with the introduction and rapidly increasing sophistication of e-government and information and communication technology (ICT), this tradeoff between citizen participation and administrative efficiency is said to have been reduced if not completely eliminated (Im et al., forthcoming). This has ostensibly helped simplify policymakers' decisions to increase transparency and accountability of government processes, and as such also stands to improve the quality of democracy (Brewer et al., 2006; Gerodimos, 2006; UNPAN, 2010).

Prior research on e-government adoption suggests that internal actors are unlikely to embrace new technologies for the sake of enhancing external transparency and accountability alone, but rather as a mechanism for managing unpredictability (Yildiz, 2007) and reaching organizational goals (Ahn \& Bretschneider, 2011; Fountain, 2001; cf. Halachmi, 2002). To this end, government use of externally oriented applications of e-government may be more likely if internal actors believe such applications will better enable the bureaucracy to cope with potential environmental disturbances (Fiol \& Lyles, 1985), thereby offering the potential to improve performance. Internal actors, according to existing e-government literature, can be considered to include decision makers such as senior-level managers, as well as subordinates responsible for implementing e-government applications (Ho, 2002; Morris \& Moon, 2005).

Thus, participatory applications of e-government are likely to play a major role in influencing the way in which internal actors manage the bureaucracy's relationships with its environment (Ahn \& Bretschneider, 2011; Yildiz, 2007). Subsequently, it can be assumed that internal actors charged with crafting participatory e-government applications, such as senior-level managers, will seek to adopt this technology only if it allows the bureaucracy to achieve greater organizational stability or realize other objectives (Ho \& Ya Ni, 2004), while simultaneously placating demands by external actors for greater transparency and accountability.

Thus, a tension exists between sources external to the government, who advocate participatory applications of e-government as a means of reigning in closed-doors bureaucrats, and internal government actors, who are cautious about, if not resistant to, opening their organization to potentially destabilizing external forces. Thus, the form e-government applications take in practice are often said to be functions of pressures from inside and outside government (Fountain, 2001). As such, contextual features, through their influence on the way external and internal actors articulate their demands, are likely to play a formative role in shaping the way e-government is applied within a particular setting.

Perhaps one of the best-known frameworks for explaining the interplay between 
contextual features and e-government applications is Fountain's (2001) technological enactment framework. Through this framework, Fountain argues that various internal and external sources of pressure, which are shaped by various contextual features of the environment within which an organization operates, serve to influence the way in which a new technology is adopted. As Yildiz explains Fountain's framework, "technology is customized to the needs and the environment of a specific organization through the process of enacting" (2007, p. 653), where enacting can be considered synonymous with application, and needs and environment pertain to the formative influence of the political, social, and economic contexts.

However, as some have noted, Fountain's “technological enactment framework often overemphasizes the importance of internal contextual features (i.e. inter-organizational politics), and therefore discounts the importance of the role that external contextual features play in influencing the way in which e-government is adopted (Norris, 2003). Thus, as internal and external characteristics of the context in which e-government applications are pursued serve to influence the form e-government takes, it also stands to reason that both internal and external contextual features will play an important role in influencing the success of one form of e-government policy vis-à-vis another (cf. Norris, 2003).

\section{THE INFLUENCE OF CONTEXT ON THE SUCCESS OF EGOVERNMENT APPLICATIONS}

An ample body of literature has explored the way in which certain features of an environment influence e-government programs (Fountain, 2001; Heeks, 2003). However, to date there have been few empirical attempts to understand how contextual features influence the success of different types of e-government applications, such as internally or externally oriented applications. As e-government matures in practice and in theory, greater diversity can be found in the ways in which this tool can be and is applied (see Im et al., forthcoming). Consequently, it is important for research to specify which contextual factors influence the success of particular e-government applications, rather than viewing them at an aggregate and general level, as has been most common until now. This study attempts to determine contextual factors of particular relevance to participatory applications of e-government from among the factors described in the existing literature as relevant to e-government in general.

Of the numerous factors discussed in the literature on the sustainability of egovernment programs, three broad categories - political, social, and economic — can be identified as likely to play an important role in determining the shape of e-government 
applications as well as their success (Chadwick \& May, 2003; Fountain, 2001; Heeks, 2003; Ho, 2002; Im et al., forthcoming; Kumar \& Best, 2006; Norris, 2003; Yildiz, 2007; Zanello \& Maassen, 2011). ${ }^{3}$ As this study represents an initial attempt to explore factors influencing the success of participatory applications of e-government, these three broad categories will be used to derive more discrete factors (for example, technological, infrastructural, cultural, or legal) that can be empirically explored in greater depth by future research.

The following section has two intentions: (1) to discuss the theoretical and practical relevance of these categories of contextual factors in order to illustrate why their presence or absence may influence participatory applications of e-government, and (2) to identify similarities and differences in the presence of these factors in Romania and South Korea.

\section{The Political, Economic, and Social Contexts in Romania and South Korea}

Zanello and Maassen (2011) observe that adoption of information and communication technologies (such as e-government) within a given context is often seen as contingent upon factors related to infrastructure, literacy, income, and perceived need-and that lack of resources, political interference, and poor policy design and implementation are major sources of failure or unsustainability. Marked similarities and differences with regard to the aforementioned factors in Romania and South Korea make a comparison of participatory e-government applications in these two nations particularly interesting.

\section{Similarities}

Romania and South Korea both began their democratic transitions in the late 1980s, Romania in 1989 and South Korea in 1987. Today, democracy in both nations is recognized as free and fully functional (Freedom House, 2011). Both have adopted semipresidential political structures. In both nations, the office of the president is typically viewed as more powerful than the legislative and judicial branches and other positions in government, such as the office of the prime minister.

These similarities in political structure imply that internal sources of pressure that

3. Fountain's enactment framework suggests the importance of political and social factors in the adoption of information and communication technologies, such as e-government, whereas Zanello and Maassen, to some degree elaborating upon this framework in developing nations, also suggest that economic factors play a major role. 
influence e-government programs (availability of resources or political interference) will be similar relative to other governments (cf. Pollitt \& Bouckaert, 2004). The ways in which internal actors articulate their demands are also likely to be similar, and thus interorganizational politics are likely to play out in a similar fashion in both countries (cf. Peters, 1998). Finally, given the strength of the executive branch vis-à-vis other branches of central government, as well as the unitary system of government found in both nations, similar formal oversight and accountability mechanisms will be present at the central, regional, and local levels of government, which together influence bureaucrats' use of discretion during the formative implementation stage of e-government applications (Kumar \& Best, 2006; Lipsky, 1971).

A further similarity between Romania and South Korea concerns the influence of culture on citizens' predisposition toward political participation. Both countries, for most of the 20th century, were governed by authoritarian regimes. The Romanian Communist Party, which came into power shortly after World War II and remained at the helm until 1989, pursued a series of policies that drastically increased the power of the state vis-à-vis nongovernment actors, which in turn substantially reduced levels of civic engagement (Badescu \& Sum, 2005). Uslaner (2004) has found that, although Romania began its democratic transition in the early 1990s, due to the state-centric policies pursued earlier by the Romanian Communist Party, levels of civic engagement and citizen participation in government still remain low when compared to other western nations.

South Korea also has a long history of state-centric political culture, influenced by Confucian philosophy and Koreanized manifestations of Confucian principles, such as sil-hak, which likens the role of good government to that of a caring parent, and the role of the citizen to that of an obedient child ( Sen, 1997). This perspective on the relationship between citizens and their government has contributed to traditionally low levels of civic engagement and citizen participation in government in South Korea. ${ }^{4}$ These tendencies endured long into the 20th century, in part due to a series of generals who autocratically governed the nation from the early 1960s to the late 1980s. Only in the mid 1990s, due to government funding of various nonprofit groups in order to deepen democratic reforms, did levels of civic engagement and citizen participation increase. However, when compared to levels of civic engagement and participation (other than voting) in western nations, South Korea's remain relatively low.

A final similarity between Romania and South Korea, which has particular influence on participatory e-government applications, is median age, estimated at 38.7 in Romania and 38.4 in South Korea (CIA, 2011). Many studies have found that younger citizens

4. An additional factor concerns Japan's occupation of South Korea. 
more likely to participate in politics than older citizens. Age is also commonly highly correlated with Internet use (Lee, 2003; Tolbert \& McNeal, 2003). The relatively recent establishment of democracy in Romania and South Korea also makes it likely that younger citizens will be more receptive to participatory applications of e-government, as they are likely to have been socialized to espouse democratic values. As both nations experienced democratic transition at similar times, they are likely to have similar intergenerational differences in this regard.

\section{Differences}

While many of the similarities mentioned above are political, cultural, or age-related, differences between Romania and South Korea primarily concern their economies and the presence of ICT infrastructure (which these authors consider to be a result of economic conditions). Perhaps the most poignant concerns their economies, with South Korea's economy estimated to be nearly three times as large as Romania's and the per capita gross domestic product of a South Korean citizen nearly three times that of a Romanian citizen. This disparity is significant for this research for three reasons:

1. It suggests a substantial difference between the two governments' ability to fund e-government programs. Resource scarcity makes a government less likely to divert funds to new projects and more likely to focus on existing processes in hopes of making them more efficient. It is also likely to stimulate greater debate in parliament about use of funds.

2. It implies a difference in citizens' ability to afford important prerequisites for e-government use, such as computers and Internet subscriptions (cf. Zanello \& Maassen, 2011) — and thus, in their perception of the need for participatory e-government and the likelihood that they will exert pressure on government to provide it.

3. There is a sharp difference in broadband penetration, with an estimated 13.96 connections per 100 citizens in Romania as of 2010 and 36.63 per 100 in Korea (ITU, 2011). ICT infrastructure has consistently been evaluated as underdeveloped in Romania and highly developed in Korea (UNPAN, 2010). Enhancing participatory e-government applications in Romania may be financially prohibitive, as it would likely first require large investments in ICT infrastructure.

A final point that bears mentioning here is that, during the time the e-guvernare project was conceived of and implemented, Romania was enthusiastically pursuing membership in the European Union. Membership has reduced the autonomy of Romanian bureaucrats and politicians in creating and implementing policies, including 
those related to e-government, and has given European Union officials a substantial degree of influence over Romanian policy making. This extra layer of political influence was missing from the South Korean context, which is notable for its strong and consolidated bureaucratic orientation and lack of political interference (Im et al., forthcoming).

\section{CASE STUDY: PARTICIPATORY E-GOVERNMENT IN ROMANIA AND SOUTH KOREA}

The cases chosen for comparison in this study are the Romanian government's e-guvernare portal ) and South Korea's Government 4 Citizens project (G4C). These programs were chosen for three interrelated reasons. First, they both exhibit an external orientation in that they intend to solicit greater citizen use of and participation in government services. Second, both introduce mechanisms to enhance external accountability and transparency to the public. Third, both include a service component, shifting services that at one time could only be obtained in person to an online format that citizens could access without leaving their home or office. Korea's G4C project is largely considered a success, while Romania's e-guvernare project is considered unsuccessful (Popescu, 2010).

In measuring the success or failure of participatory e-government projects, it is perhaps most difficult to specify criteria for success. Citizens' use of e-government is one such criterion. However, as Kumar and Best (2006) have demonstrated, while this may initially be very high, it may not be sustainable. A third key criterion is the quality of the services, which this study assesses based on the interoperability of front- and back-end processes. 5 Thus, this framework for assessing the success of e-government relies on three factors: citizen use, sustainability, and interoperability. Bearing in mind the theoretical discussion in the previous sections, as well as the similarities and differences between Romania and South Korea, a more detailed assessment of these two programs follows.

5. The front end refers to the aspects of e-government with which citizens interact directly. The back end refers to the administrative mechanisms for processing those citizen interactions. If the front and back ends of e-government applications are not sufficiently integrated, citizens' ability to use them to interact with government will be limited. 


\section{Romania's E-guvernare Project}

The intent of the e-guvernare project, launched in 2003, is to "reduce bureaucratic administrative barriers and simplify [citizen] access to [government] information and services" (CNMSI, 2011). In this way, policy makers hope to increase the external transparency and accountability of government processes in order to reduce corruption (Ion, 2008). Taken together, these points constitute part of a broader reform agenda referred to as the desk reform. The objective of this reform is to use participatory egovernment applications to enhance government efficiency and to increase the number of citizens who are able to interact with their government and the frequency of their interactions (www.e-guvernare.ro, 2011). Thus, the program is both internally and externally orientated. It is supervised by the Agency of Information and Society Services in the Ministry of Communications and Information Technology. Much of the work done by these actors was, in turn, reported to representatives of the European Union.

Support for the e-guvernare project was initially broad, both within the Romanian government and among citizens. The project was also heavily influenced and supported by the European Union. However, a key problem was that details of e-government reform bills were modified and amended frequently Zahan and Costake (2007)—a phenomenon which, while not unique to Romania, is often found to diminish the likelihood of success of e-government projects (Heeks, 2003; Kumar \& Best, 2006). Much of the e-government legislation in Romania came after the e-guvernare portal was launched (Silvestru, Codrin, Rentea, Pavel, \& Mina, 2009).

These frequent changes to legislation suggest either that e-government projects in Romania are likely to be subjected to a great deal of political dealing between ruling and opposition parties, or that the Romanian government tends to quickly implement e-government projects without a careful assessment of necessary prerequisites. Under both scenarios, a coherent picture of how the e-guvernare portal intends to achieve its ambitious agenda is missing, as is a well-thought-out plan.

While the e-guvernare portal's objectives were ambitious, it is cited as a failure (Sandor, 2006). Among the potential reasons for this lack of success, three factors in particular can be identified; they are related to the success factors specified earlier (citizen use, sustainability, and interoperability of front and back ends). These three interrelated factors can be attributed to the actions of both internal and external actors and related to economic, political, and social conditions.

First, attempts to integrate back- and front-end systems failed. Dana Popescu of the Agency of Information and Society Services, one of the bodies responsible for the e-guvernare project, explains: 
Taxpayers were given digital certificates issued by the [Agency], which although they have taken, they could not use. The reality was that they did not have protocols with [the] National Agency for Tax Administration, House of Unemployment, etc. . . . In fact at that time I was told that the system cannot handle work and data traffic over older servers by National Electronic System. (Popescu, 2010)

While measures were taken to enhance interoperability between the front- and back-end systems, such as the creation of the National Electronic SystemES, Popescu's observation suggests that these measures failed due to a lack of interoperability of back-end processes. Without first pursuing interoperability between the multiple backend processes of agencies whose services were migrating online, it is of little surprise that interoperability between front- and back-end processes faltered as well. The lack of interoperability can ultimately be attributed to economic factors.

The second factor contributing to the lack of success of the e-guvernare program was the fundamental lack of infrastructure; without it, citizens' use of the portal was limited and fell far short of its ambitious goals. Sandor (2007), citing a study on egovernment readiness published by the Economist Intelligence Unit in 2006, has argued that the infrastructure necessary to support e-government initiatives is largely underdeveloped. Indeed, this theme is present throughout much of the literature on e-government in Romania (Sandor, 2006; Sivestru et al., 2009). The absence of infrastructure can be considered related to economic factors. Thus, the ensuing question is why such an ambitious e-government project would be pursued by the Romanian government in the absence of necessary economic resources such as infrastructure.

The answer to the above question may be found in the third factor, which concerns politics. Given that Romania is a member of the European Union, the politics influencing e-government adoption involve actors at both the EU and national levels. Given the benefits e-government adoption is said to have on consolidation of democracy, the European Union has been a firm advocate of participatory applications of e-government in new member states in Central and Eastern Europe (Silvestru et al., 2009). In this case, as Romania is the recipient of European Union grants and other support, domestic politicians and government officials (internal actors) are charged with placating the demands of European Union officials (external actors).

Given the relationship between the internal and external actors, it appears likely that the decision to implement such an ambitious participatory e-government application, without first ensuring that necessary prerequisites were in place, could be attributable to Romanian politicians' over-eagerness to satisfy the demands of European Union officials, and their apparent lack of concern about the success of the e-guvernare 
portal. This explanation is supported by the flurry of amendments and legislation that occurred following the implementation of the portal, suggesting that this major project was implemented without a great deal of planning. Thus, the pervasiveness of political dealing with respect to the e-guvernare portal that took place within the Romanian government, as well as between the Romanian government and the European Union, negatively affected the portal's sustainability.

As suggested above, poor infrastructure, which these authors consider an economic factor, contributed significantly to the project's lack of success. Without sufficient infrastructure, the interoperability of front- and back-end processes became a major issue. The apparent decision not to ensure the necessary economic prerequisites or a coherent strategy for this ambitious project was a political one, likely related to Romanian officials' perceived need to fulfill European Union demands.

\section{South Korea's G4C Project}

"The G4C project arose from the need to provide a better set of services to the public, as well as increase administrative efficiency and transparency" (MOPAS, 2011). Launched in 2000, the G4C project, like the e-guvernare project in Romania, was intended to improve the efficiency with which the government interacted with citizens and to solicit greater citizen use of public services, suggesting both an internal and external orientation for the project. However, the G4C project differs from the eguvernare project in its ambition, in that while the e-guvernare project was to serve as a component of an overarching reform agenda, the G4C project was pursued in an effort to enhance Korea's competitive capacity with respect to public service delivery (MOPAS, 2011).

While the G4C project was officially launched in 2000, the Ministry of Public Administration and Security began preparations for it in the early 1990s, largely focusing on developing the infrastructure needed to sustain the delivery of services online. To this end, before initiating the project, great efforts were made internally to ensure that the back-end processes of different offices could interact effectively. Once this was achieved, front-end processes were progressively, albeit conservatively, targeted. Implementation of the $\mathrm{G} 4 \mathrm{C}$ was primarily left to the Ministry of Public Administration and Security.

The G4C project enjoyed sustained support by internal actors such as politicians and public officials, as well as external actors throughout society. However, it was mainly implemented by the state bureaucracy, largely independent from external actors and politicians. To this end, a coherent long-term strategy was developed for the project. For example, the Ministry of Public Administration and Security outlined the 
developmental timeline of the G4C project in terms of three stages that span nearly 15 years, with citizen-oriented processes only being pursued energetically in the last stage (MOPAS, 2011). Thus, while the Romanian government appears to have taken a hasty approach to e-government, the Korean approach appears to have been more cautious and strategic.

Today the G4C project is typically viewed as a great success. Three interrelated success factors can be identified; they are primarily attributed to the actions of internal actors and related to economic and political factors. The first was the long-term perspective that informed the planning and implementation of the G4C project, which in itself implies a heavy emphasis on sustainability. While the G4C project has come into the spotlight only over the past five years or so, preparations for it began as much as 15 years ago.

This long-term perspective suggests that the Korean government viewed the G4C project as an investment rather than a reform. Indeed, the fact that the government saw the $\mathrm{G} 4 \mathrm{C}$ project as a means of enhancing national competitiveness speaks to this fact in particular. Furthermore, an emphasis was placed on identifying prerequisites necessary to the project and then establishing strategies for fulfilling them. To this end, while little of the infrastructure needed for implementation existed at the conception of the G4C project, the development of infrastructure was heavily emphasized in the G4C strategy (MOPAS, 2011). This helped to ensure that citizens would be able to make widespread use of the project upon implementation.

The second success factor was ensuring the interoperability of the different backend processes before working on the interoperability of front- and back-end processes. This factor is related to ensuring that needed infrastructure is in place, as well as to the careful establishment of a segmented strategy of implementation. By emphasizing infrastructure, the Korean government was able to ensure that various areas of government possessed the tools needed to interact with each other, thereby establishing a foundation for the eventual creation of participatory applications of e-government such as the $\mathrm{G} 4 \mathrm{C}$ project. Here, too, emphasis was clearly placed on ensuring that citizens would be able to make widespread use of the G4C project.

The third success factor is related to the political environment in which the G4C project was carried out, and is closely related to sustainability. As mentioned earlier, responsibility for the G4C project largely fell to the Ministry of Public Administration and Security, which is answerable primarily to the president and the parliament. The ministry experienced little interference from politicians in parliament, but did experience significant adjustments as presidential administrations changed. This is relevant for two reasons. First, the length of South Korea's presidential terms (five years) may have provided the G4C program, in its initial form and during subsequent reforms, 
with relative continuity. Second (also related to continuity), only a few sources existed for pressure to adjust the program — namely, bureaucrats in the Ministry of Public Administration and Security and the president. This continuity very likely contributed to the ability to develop and execute long-term initiatives.

The Korean case appears quite different from the Romanian case, despite the apparent similarities between these two nations with respect to economic, political, and social factors. Concerning economic factors, while Romania attempted to implement a participative e-government project and develop the infrastructure to support it at the same time, Korean officials appear to have worked hard to ensure that the G4C project was only made participative once the necessary infrastructure was present. This could be considered a more ambitious assumed participation perspective (in Romania) versus a planned participation perspective (in South Korea. Moreover, by ensuring that infrastructure was in place, the Korean government was also able to enhance the interoperability of back-end processes, thereby facilitating eventual citizen participation. Regarding political factors, the reason the government was not forced to rush into implementing a participative e-government project may be its more streamlined decision-making process, partially resulting from the relative absence of politics from the decision making process in the case of the $\mathrm{G} 4 \mathrm{C}$ project.

While the above discussion has stressed the importance of political and economic factors in the success of participatory applications of e-government, this is not to suggest that social factors are not important. Rather, it suggests the importance of sequencing the development of such applications. While citizen use, sustainability, and interoperability are all important criteria for gauging the success of participatory applications of e-government, the points in time at which each should be emphasized appear to be different. In particular, political and economic factors appear to be fundamental to ensuring that participatory applications of e-government possess sufficient interoperability and are sustainable. As such, these two factors, as illustrated by the G4C case, also lay a foundation for expanded citizen use of e-government; if political and economic foundations are insufficient, as was the case with the e-guvernare project, then social factors may be of little relevance, at least in the early stages.

\section{IMPLICATIONS}

Social factors did not contribute heavily to the success or failure of the e-guvernare and $\mathrm{G} 4 \mathrm{C}$ projects at the outset. Comparison of the two projects suggests that for social factors to contribute to the success or failure of a participatory e-government project, consistency and a long-term perspective are essential. In other words, social factors 
may be of less immediate concern than political and economic factors, which are likely to play a decisive role, at least in the short term.

Another important lesson gleaned from Romania's and South Korea's experiences, which may be seen as stemming from the primacy of political and economic factors, is the importance of planning to the success of participatory e-government applications in particular, and perhaps e-government more generally. In the case of Korea's G4C project, planning and execution were largely left up to a single internal actor, the Ministry of Public Administration and Security. Conversely, responsibility for planning and execution of Romania's e-guvernare project was spread among various internal actors, thereby contributing to a lack of consistency and making the formulation of a single coherent vision for the project more difficult. Further complicating the picture was the involvement an external actor, the European Union, which possessed great influence over the planning and implementation of the project and served as a source of pressure on Romanian officials, who at the time were eagerly pursuing accession to the European Union.

Comparison of the G4C and e-guvernare projects also suggests that in order for infrastructure to be developed and interoperability enhanced, the development of infrastructure must be marked as an area of strategic competitive importance by politicians, perhaps even more so in less economically developed contexts. This also implies that timelines for the implementation of participatory applications of e-government are best considered from a long-term perspective, particularly in contexts where resources are scarce, such as Romania. In South Korea, participatory applications of e-government were treated by politicians and bureaucrats as a long-term objective; they concerned themselves with satisfying prerequisites first, rather than simultaneously pursuing both objectives. Evidence for this can be found in government documents dating back as far as 1995, at which time South Korea's economy was considerably smaller than it is today (MOPAS, 2011). Acknowledging limited resources, but also acknowledging the desire to use information and communications technology as a means of enhancing citizen participation, the government pieced together what it viewed as a gradual yet achievable plan.

International organizations often push for rapid adoption of participatory applications of e-government in an effort to consolidate and enhance democracy, applying such arguments indiscriminately to wealthy and poor nations alike (UNPAN, 2010). The European Union played an important if not decisive role in accelerating Romania's adoption of a participatory e-government program, when in fact this course of action appears not only to have been ineffective in enhancing democracy, but also to have resulted in the inefficient use of resources.

A final point that bears mentioning, which also relates to political and economic 
factors, concerns the way in which benefits associated with participatory e-government applications were framed by the actors involved. South Korea's G4C project was argued by its founders to serve as a primary means of enhancing government competitiveness by means of enhanced provision of public services, which in turn would stimulate economic benefits. As such, its objective was framed in narrow terms, and associated with a set of tangible benefits, in addition to various intangible benefits.

By contrast, Romania's e-guvernare project framed its benefits in more ambiguous, less tangible terms, ranging from European Union accession to enhanced democracy to happier citizens. Subsequently, the way in which benefits were associated with the project was more open to debate and therefore to frequent change. Consequently, maintaining a coherent vision for the project proved difficult. This suggests that the way in which the benefits associated with participatory applications of e-government are framed is likely to have a major influence upon the political context in which the application is implemented. To this end, vaguely described benefits may intensify the political debate over such projects, whereas more concrete and specific benefits may be more difficult to debate and may translate into greater consistency and simplify the formulation of a long-term plan.

\section{CONCLUSION}

This study contributes to e-government research in two ways. First, it has attempted to better understand conditions conducive to the viability of participatory applications of e-government. Until now, studies of e-government have treated it as an aggregate concept, yet with the passing of time and the advancement of technology, e-government applications are becoming more diverse, thereby requiring research to focus on particular applications in order to be useful.

Moreover, given the widespread calls for greater participatory applications of egovernment, comparative research addressing successful and less successful applications is needed. This comparison of projects in Romania and South Korea suggests that the ability to carry out long-term planning, which is affected by a nation's political context, is fundamental to the success of participatory e-government projects. With long-term planning, economic factors can be better accommodated and necessary prerequisites met in a feasible fashion, thereby ensuring the viability of eventual citizen participation. In the case of South Korea, this was done by adopting e-government as part of an overarching and incremental strategy to enhance government competitiveness. Conversely, participatory applications are likely to fail if they are rushed. Moreover, the successful creation of a long-term plan is likely to be associated with the way in which 
benefits stemming from participatory applications of e-government are framed.

The second contribution of this study to the literature is that it builds upon the existing body of knowledge related to e-government in Romania, which is underrepresented in the English-language literature. Moreover, it compares Romania's egovernment to that of South Korea, a nation well known for its e-government program. Through such a comparison, it is possible to explore how differences and similarities between the two countries contribute to their success or failure in adopting participatory e-government applications. The findings resulting from such a comparison are fairly intuitive and possess a universal nature, implying that they should also be easily generalizable to participatory applications of e-government in various contexts, ranging from wealthy, advanced nations to those with fewer resources.

\section{REFERENCES}

Ahn, M. J., \& Bretschneider, S. 2011. Politics of e-government: E-government and the political control of bureaucracy. Public Administration Review, 71: 414-424.

Badescu, G., \& Sum, P. 2005. Historical legacies, social capital and civil society: Comparing Romania on a regional level. Europe-Asia Studies, 57(1): 117-133.

Brewer, G. A., Neubauer, B. J., \& Geiselhart, K. 2006. Designing and implementing e-government systems: Critical implications for public administration and democracy. Administration \& Society, 38(4): 472-499.

CIA (Central Intelligence Agency). 2011. The World Factbook. Washington, DC: Author.

Chadwick, A., \& May, C. 2003. Interaction between states and citizens in the age of the Internet: "e-government" in the United States, Britain and the European Union. Governance: An International Journal of Policy and Administration, 16, 271-300.

CNMSI (National Centre for the management of social information). 2012. E-guvernare web portal, home page. Retrieved April 22, 2012, from http://www.e-guvernare .ro/Default.aspx?LangID=4.

Dahl, R. 1989. Democracy and its critics. New Haven: CT: Yale University Press.

Danziger, J. N., \& Andersen, K. V. 2002. The impacts of information technology on public administration: An analysis of empirical research from the "golden age" of transformation. International Journal of Public Administration, 25(5): 591-627.

Denhardt, R. B., \& Denhardt, J. V. 2000. The new public service: Serving rather than steering. Public Administration Review, 60(6): 549-559.

E.I.U. (The Economist Intelligence Unit). 2006. The 2006 e-readiness rankings: A 
white paper paper from The Economist Intelligence Unit, Author.

Fiol, C. M., \& Lyles, M. 1985. Organizational learning. Academy of Management Review, 10(4): 803-812.

Fountain, J. 2001. Building the virtual state: Information technology and institutional change. Washington, DC: Brookings Institute.

Freedom House. 2011. Freedom in the world 2011: The authoritarian challenge to democracy. Washington, DC: Author.

Gerodimos, R. 2006. Democracy and the Internet: Access, engagement and deliberation. Systematics, Cybernetics and Informatics, 3(6): 26-31.

Halachmi, A. 2002. Performance measurement and government productivity. Work Study, 51(2): 63-73.

2005. Performance measurement is only one way of measuring performance. International Journal of Productivity and Performance Management, 54(7): 502-516.

Heeks, R. 2003. Most egovernment-for-development projects fail: How can risks be reduced? Retrieved April 22, 2012, from http://unpan1.un.org/intradoc/groups/ public/documents/NISPAcee/UNPAN015488.pdf.

2005. E-government as a carrier of context. Journal of Public Policy, 25: 51-74.

Ho, A. 2002. Reinventing local governments and the e-government initiative. Public Administration Review, 62(4): 434-444.

Ho, A., \& Ya Ni, A. 2004. Explaining the adoption of e-government features: A case study of Iowa County Treasurers' Offices. American Review of Public Administration, 34(2): 164-180.

Im, T., Porumbescu, G., \& Lee, H. forthcoming. ICT as a buffer to change: A case study of the Seoul Metropolitan Government's Dasan Call Center. Public Performance and Management Review.

ITU (International Telecommunications Union). 2011. Measuring the information society. Geneva: Author.

Irvin, R. A., \& Stansbury, J. 2004. Citizen participation in decision making: Is it worth the effort? Public Administration Review, 64(1): 55-65.

Kraemer, K. L., \& King, J. L. 2006. Information technology and administrative reform: Will e-government be different? International Journal of Electronic Government, 2(1), 1-18.

Kumar, R., \& Best, M. 2006. Impact and sustainability of e-government services in developing countries: Lessons learned from Tamil Nadu, India. The Information Society, 22: 1-12.

Layne, K., \& Lee, J. 2001. Developing fully functional e-government: A four stage 
model. Government Information Quarterly, 18: 122-136.

Lee, A.-R. 2003. Down and down we go: Trust and compliance in South Korea. Social Science Quarterly, 84(2): 329-343.

Lipsky, M. 1971. Street level bureaucracy and the analysis of urban reform. Urban Affairs Review, 6(4): 391-409.

Macintosh, A. 2004. Characterizing e-participation in policy making. Proceedings of the 37th Hawaii International Conference on Systems Sciences, January 5-8, 2004, Big Island, Hawaii. IEEE.

Michels, A. 2011. Innovations in democratic governance: How does citizen participation contribute to a better democracy? International Review of Administrative Sciences, 77(2): 275-293.

Moon, M. J., and Norris, D.F. 2005. Advancing e-government at the grassroots: Tortoise or hare? Public Administration Review, 65(1): 64-75.

MOPAS (Ministry of Public Administration and Security). 2011. E-government plans for 21st century. Seoul: Author.

Neshkova, M. I., \& Guo, H. 2011. Public participation and organizational performance: Evidence from state agencies. Journal of Public Administration Research and Theory, 21(4), 267-288.

Norris, D. F. 2003. Building the virtual state ... or not: A critical appraisal. Social Science Computer Review, 21(4): 417-424.

Peters, G.B. 1998. Managing Horizontal Government: The Politics of Co-Ordination. Public Administration, 76(2):295-311.

Pollitt, C, and Bouckaert, G. 2004. Public Management Reform: A Comparative Analysis. Second Edition. Oxford: Oxford University Press.

Popescu, D. 2010. Chaos in the strategies and e-governance system of Romania. ASSI Public Declaration, September 2010.

Sandor, S. D. 2006. Romania's digital divide and the failures of e-government. Transylvanian Review of Administrative Sciences, 16: 154-162.

. 2007. E-government in Romania. In Klumpp (ed.), One-stop-Europe: Citizen centered government (pp. 5-10). Alcatel-Lucent Stiftung, Germany.

Sen, A. 1997. What Lee Kuan Yew and Ling Peng Don't Understand about Asia: Human Rights and Asian Values. The New Republic, 217: 33-40.

Silvestru, C., Codrin, N., Rentea, C., Pavel, A., \& Mina, L. 2009. Analysis of requirements and design approaches for Romania from the perspective of the EU services directive. Transylvanian Review of Administrative Sciences, 26: 170-188.

Snellen, I. 2007. E-government: A challenge for public management. In E. Ferlie, L. E. Lynn, \& C. Pollitt (eds.), The Oxford handbook of public management. New York: Oxford University Press. 
Stivers, C. 1990. The public agency as polis: Active citizenship in the administrative state. Administration and Society, 22(1): 86-105.

Thomas, C. 1998. Maintaining and restoring public trust in government agencies and their employees. Administration and Society, 30(2): 166-193.

Tolbert, C., \& McNeal, R. S. 2002. Unraveling the effects of the Internet on political participation. Political Research Quarterly, 56: 175-185.

UN \& ASPA (United Nations \& American Society for Public Administration). 2001. Benchmarking e-government: A global perspective. New York: United Nations Publications.

UNPAN (United Nations Public Administration Network). 2010. United Nations egovernment survey 2008: From e-government to connected governance. New York: Author.

Uslaner, E. 2004, September. Coping and social capital: The informal sector and the democratic transition. Paper presented at the conference Unlocking Human Potential: Linking the Formal and Informal Sectors, Helsinki.

Vu, K.M., and West, D.M., E-government and Business Competitiveness: A Policy Review. 2005. Vietnam Competitiveness Initiative. Welch, M., Hinnant, C. C., \& Moon, M. J. 2005. Linking citizen satisfaction with e-government and trust in government. Journal of Public Administration Research and Theory, 15(3): 371-391.

Yang G. 2003. The Internet and civil society in China: A preliminary assessment. Journal of Contemporary China, 12: 453-475.

Yildiz, M. 2007. E-government research: Reviewing the literature, limitations, and ways forward. Government Information Quarterly, 24(3): 646-665.

Zahan, E, and Costake, N. 2007. Priorities for e-government in European transforming countries: Example of Romania. International Conference on e-Government, University of Quebec at Montreal, Canada, September 27-28, 2007.Reading, UK: Academic Conferences Limited.

Zanello, G., \& Maassen, P. 2011. Strengthening citizen agency and accountability through ICT. Public Management Review, 13(3): 363-382. 